\title{
The Attitude of Romanian Industrial Companies towards the Market during the Transition
}

\section{Ion Voicu Sucala}

Technical University of Cluj-Napoca, Memorandumului 28, 400114, Cluj-

Napoca, Romania, voicu.sucala@ mis.utcluj.ro

University of Glasgow, 8-9 Lilybank Gardens, G12 8RZ, Glasgow, United

Kingdom, i.sucala.1@ research.gla.ac.uk

\section{Adriana Sava}

Technical University of Cluj-Napoca, Memorandumului 28, 400114, ClujNapoca, Romania, adriana.sava@mis.utcluj.ro

\begin{abstract}
The paper presents the evolution of the market orientation of Romanian industrial companies in the first two decades of the post-communism period. While in the first decade of transition the market orientation was almost in-existent, at the end of the second decade a strong commitment towards marketing performance has been identified. The dimensions of marketing performance that emerged as most important were market performance, customer performance and marketing's financial performance. However the companies' average ability to measure marketing performance was slightly less than adequate.
\end{abstract}

Keywords: industrial organizations; Romanian companies; market orientation; marketing performance measurement; post-communist transition

\section{Introduction}

The paper addresses an important aspect of the evolution of the post-communist Romanian industry - market orientation. After more than forty years of command economy, characterised by a rigid system of centralised planning, the development of the orientation to the client's needs has been an important challenge for Romanian industrial organizations. The lack of a consistent industrial tradition, the extensive industrialisation process during the communist regime, and the obsessive focus on the heavy-industry are some of the factors that have affected 
the post-1989 evolution of the Romanian industry. The post-communist Romanian elites had been less oriented towards market economy as Sucala [42] argued. The cultural impact on Romania's historical evolution has also been analysed elsewhere [43] [44]. Because of the complex evolutions experienced by Romania during the transition, and because of the scarce statistical sources available especially regarding the first decade of transition, a complex qualitativequantitative methodology had been used in order to obtain a better understanding of the managers' attitude regarding the market and marketing performance. These aspects had been investigated in two different periods, using two different methodologies. Since in the first decade of transition there were no reliable statistics regarding companies' performances, a qualitative methodology was used to analyse archived conversations between students and managers. The conversations were recorded between 1994 and 1997. The findings show a significant disconnection between companies and the market, partly generated by the communist system's demise and partly by the companies' lack of competences and structures. The same aspect had been investigated after 2010, using a quantitative methodology. The results indicate a stronger orientation towards market, customer and marketing performance measurement.

The paper is structured as follows: presented in the first part are three main characteristics of the Romanian economy - the legacy of backwardness, the communist extensive industrialisation and a few main characteristics of the transition process. In the second part the complex methodology used in the research is described. The findings are presented in the last part, including the most significant conclusions, research limitations and possible directions of future research.

\section{The Context}

\subsection{The Historical Legacy}

The discrepancies between Romania and the Western countries were the subject of an intense debate among the Romanian elite. Usually, the disparity between Romania and Europe was discussed in Romanian literature from three main points of view - economic, political and cultural. Since the problem of measuring economic and social differences is a complex one and it isn't the objective of this paper, presented here will be the historical evolution of the main social and economic disparities between Romania and the other European countries, as it results from the existing literature.

Murgescu [31] had made an extensive analysis of the economic disparities accumulated in the last five centuries. The development of the Romanian 
principalities during the XVI-XVIII centuries was in line with the European average, therefore the disparity had remained relatively constant. The real problem concerned the economic development model which was based on an extensive exploitation of resources and allowed population growth without a consistent change of the economic structures. Axenciuc [6] considers that the overall economic result of the period between 1859 and 1914 was positive. The transition from feudal society towards a modern one, with an economy based more on trade than on self-consumption, with a new legal and institutional systems, with an infrastructure and an industry in process of development were the most important achievements of this period. But in the same period, Maiorescu termed as 'forms without a content' - "the lack of any solid foundation for the forms we are continuously receiving from outside". This statement clearly describes a top-down modernization process in which, as Janos [20] argued, the population's expectations had exceeded the life ameliorations. Until the World War I, in spite of a consistent economic growth, the reform of the state was lagging behind. However, the pace of the modernization wasn't enough to significantly boost the economy, and the gap relative to Western Europe had increased in terms of the economic indicators.

Once World War I ended, Romania faced new challenges: its territory more than doubled and its population became a multi-national entity in which minorities accounted for almost $30 \%$. This significant increase in territory and population, and "a happy ending to the long-fought struggle for national unity seemed a most auspicious foundation for Rumania's new postwar life" [10, p. 456]. But this foundation ended in a "rather dismal history of inter-war Rumania" [idem]. The government's centralised policies performed poorly in the attempt to reconcile with the country's new status. In spite of a prevailing positive public appreciation of the economic development in the inter-war period, most of the historians agreed on the economic failure of this period. According to Murgescu [31] there are three main causes of this failure: the economic cost of the World War I, the agriculture conjuncture and the oil conjuncture. While the first cause represents a price consciously assumed by the political elite in order to achieve national unity, the other two causes were generated by inadequate government policies addressing internal and external situations.

The country was rather poorly industrialised with roughly $80 \%$ of the population living in rural areas. Roberts [36, p. 83] argued that Romania's agriculture stagnation was generated by factors such as the demographic pressure that compensated the effects of the agrarian reform in terms of average area owned by a household, the slump of the European cereals trade, the disadvantageous agriculture policies, the fragmented agricultural areas, the extensive system of exploitation and the archaic system of trade arrangements. The decline of productivity in agriculture was significant relative not only to Western countries but as well as other predominantly agricultural countries such as Hungary, Poland and Bulgaria [31, p. 228]. The increasing economic disparity among Romania, 
Europe and the world average is synthetic represented by the GDP/capita index. The figures in the table below were estimated by Murgescu [31, p. 211] who compiled them from Maddison's works.

Table 1

GDP/capita (international dollars Geary-Khamis 1990)

\begin{tabular}{|l|c|c|c|c|}
\hline & $\mathbf{1 9 1 3}$ & $\mathbf{1 9 2 9}$ & $\mathbf{1 9 3 8}$ & $\mathbf{1 9 5 0}$ \\
\hline World average & 1525 & 1806 & - & 2111 \\
\hline Average of 12 Western countries & 3688 & 4387 & 4818 & 5018 \\
\hline $\begin{array}{l}\text { Average of 7 Central and East } \\
\text { European countries }\end{array}$ & 1695 & 1942 & 1980 & 2111 \\
\hline Romania & 1741 & 1152 & 1242 & 1182 \\
\hline
\end{tabular}

After the Second World War communism took over Romania with the support of the Soviet Army and of Soviet advisers. The Romanian society "was demolished by an outside force, the Soviet Union" [25, p. 30].

\subsection{Communist Industrialisation}

The conquest of political power by the Romanian Communist Party with the support of the Soviet Army and Soviet advisers has allowed the preparation of nationalisation. After intense pressures, at the end of 1947 the Party had controlled all the state structures - public administration, the legal system, the army, and the mass-media. All "hostile elements" were purged out of these structures. At the end of May 1947 the Romanian government empowered the Minister of National Economy with control over all details of industrial production. The preparation for the centralised economy evolved from a set of political measures culminating with the nationalisation law voted by the Great National Assembly on June $11^{\text {th }} 1948$. 8894 industrial organisations precisely nominated in the law's appendixes were nationalised.

On the $1^{\text {st }}$ of July 1948 the State Commission for Planning was established and the economic ministers were re-organised based on economic sectors. From that moment on, all state enterprises had begun to operate in a centralised and strict controlled manner. All sectors of the economy were subjects of planning, but heavy industry received most of the focus while less attention was paid to agriculture, consumer goods and public services [23, p. 53].

This trend was a constant obsession during the communist regime. Once again the issue of backwardness had came into the mainstream discourse of the communist leadership. The promise to eliminate this backwardness was "a major constituent of official ideology" [25, p. 161] and it was based on the belief in the superiority of the socialist system's. The mitigation of this gap had been an important subject in the Romanian communist strategies and propaganda. Consequently the leaders of the Communist Party had to insist on fast growth "because it will provide 
further evidence of that superiority" [25, p. 161]. Tismaneanu et al. [46, p. 164] argued that the industrialisation conducted by the communist regime was one of the main reasons of Romania's national economic disaster.

The authors consider correctly the idea of industrialisation of a predominantly rural Romania and they argued that not everything that had been done in the line of industrialisation was wrong. But the "superhuman effort imposed on the Romanian people in the 45 years of communism had dissipated in aberrant, unproductive and non-functional investments, in creating parasitic industries, and hence in products usually of poor quality unmarketable or marketable at loss on the international market, all these amplified by huge losses caused by the stupid planning and management of the hyper-centralised economy". According to Kornai [25] the economic growth experienced by the communist states was forced, being generated not by the profound society's structure but by top-down bureaucratic decisions. This kind of growth is unsustainable and sooner or later it will slow down. After few initial efforts to fulfil the communism's basic promises, the complete fulfilment of these promises "never occurs and never can occur" [25, p. 54].

In Romania, the slowdown of economic growth had appeared later than in other communist countries [31, p. 369]. The systemic crisis of the Romanian economy in the last decade of communism had multiple causes and aspects. It was generated by internal factors but as well by the evolution of international conjuncture. Ionete [19] had argued that in the Romanian command economy the decision making system didn't create the minimal conditions for proper observation and adjustment of the economic imbalances. The stubborn refusal to adjust the economy to reality, to attenuate social tensions and the focus on the preservation of the political system had altogether amplified the unfavourable internal and external contexts. At the end of the communist regime Romania's place in the European economy had worsened both in terms of absolute and relative economic indicators, in comparison with 1938 [19, p. 28].

\subsection{Romania in Transition}

Hollinshead and Michailova [17] argued that countries such as Romania, Albania, Bulgaria, former Yugoslavian republics, or former USSR states were less successful in the achievement of economic stability in the first decade of transition. Pakulski et al. [34] considered Romania to be among the less successful cases in the same period. Hunya [18, p. 241] described Romania's evolution as a "stop-go transformation process", characterised by a considerable state influence in the economy, weak commitment to reforms, and a lack of public trust in public institutions. In a period characterised by the opposition between shock therapy and gradualism, the former being considered "a value in its own right", while the latter "was equated with timidity and unwillingness to change" [12, p. 386], Romanian elite opted for a slow reform, usually under pressures of 
external organisations such as EU, IMF or World Bank. Ahrend and Oliveira argued that Romania had been among the former communist states with the slowest privatisation of state-owned enterprises [2].

During the second decade of transition Romania had faced new challenges, opportunities and threats. The year 2000 had a double positive significance for Romania, as it was the year when Romania's economy started to recover and grow, but it also marked the beginning of negotiations regarding Romania's accession to the European Union. More radical reforms had started to be implemented in Romania, which had led to significant improvements of the country's economy. After 17 years of transition, Romania and Bulgaria formally joined the European Union on the $1^{\text {st }}$ of January 2007.

Between 2000 and 2008 together with other European emerging countries, Romania entered "in a process of accelerated growth and overall transformation", with its GDP expanding at more than 6\% per year in real terms and its GDP per capita almost doubling [13, pp. 11-12]. During those years, the Romanian economy experienced record economic growth, and at the end of 2008, before being reached by the global economic crisis, it recorded one of the highest growth rates in Europe. Nevertheless, important development differences placed Romania behind most of the EU countries and it "remains one of the poorest members of the EU" [13, p. 12].

When Romania had been hit by the economic crises it became clear that the growth model experienced by the economy before the crisis, financed by foreign money and based on consumption of imported goods, was a fragile and an unsustainable one. Economy specialists argued that "the global crisis only hastened the inevitable domestic crisis and raised its costs by adding to the preexisting problems" [11, p. 160]. Romania had no choice but to ask for financial assistance in early 2009 because of the severe negative effects of economic crisis. The International Monetary Fund, the European Union, the World Bank, the European Bank of Reconstruction and Development and other creditors jointly granted Romania a significant financial assistance package of 20 billion Euro. Drastic measures were adopted by the Romanian government, including a $25 \%$ cut of public sector wages and reduction of pensions and unemployment benefits. 


\section{Research regarding the Market Orientation and Marketing Performance of Romanian Industrial Companies}

\subsection{Market Orientation and Marketing Performance Measurement}

The market orientation literature is clearly dominated by studies investigating the relationship between market orientation and organisational performance [24], [27], the largest majority of these studies suggesting a positive association between the two mentioned concepts.

A meta-analysis based on the market orientation literature conducted by Kirca et al. [24] indicated not only a positive relationship between market orientation and business performance, but also a positive impact of market orientation on different performance measures (overall business performance, profits, sales and market share) and on various customer indicators as well (perceived quality, customer loyalty and customer satisfaction). More recently, following a survey of the market orientation research developed between 1995 and 2008, and given the amount of evidence the authors found in the literature regarding the positive association between market orientation and organisational performance, Liao et al. [27, p. 303] stated that the new research questions should focus on how and when does market orientation influence performance.

Previous works suggested that market orientation has an impact on the marketing performance assessment practices as well. According to Ambler et al. [4], the market orientation theory is one of the four theoretical perspectives that influences the choice of marketing performance measures (the other three theories are the control theory, the institutional theory and the agency theory). From the market orientation theory perspective, the degree of market orientation exhibited by a company's top management influences the extent to which top management will be interested in marketing or market performance assessment [4]. This relation influences the selection of measures managers use to evaluate marketing performance; as Brooks and Simkin [9, p. 496] note, "the level of market orientation that the firm exhibits (...) will naturally direct the choice of effectiveness measures".

This theoretical perspective is supported by various studies conducted on companies from different economies like United Kingdom [4], Spain [15], China [3] or Nigeria [33], that revealed that a company's market orientation - 
conceptualised as either customer orientation or competitor orientation ${ }^{1}$ positively influences the importance levels assigned to marketing performance measures. More specifically, companies with higher degrees of competitor orientation assign greater importance to competitive measures of marketing performance, while companies that are more customer-oriented attach greater importance to categories of customer-based indicators.

In addition, the importance assigned to marketing performance indicators seems to be influenced by company's size: customer orientation represents a stronger predictor of the importance of competition-based indicators in the case of large companies, while competitor orientation represents a stronger predictor of importance for small enterprises [4].

More recently, Mintz and Currim [28, p. 36] suggested that more marketing metrics are used in enterprises with a greater market orientation, but not more financial metrics than in their less market-oriented counterparts; this result distinguishes between marketing metrics, as metrics "based on customer or marketing mind set" and financial metrics, as metrics that are "either monetary based, based on financial ratios or readily converted to monetary outcomes".

Marketing performance measurement is no longer an option or a fad, but a vital concern for all companies, as marketing has to prove its contribution to business performance. According to a recent research conducted among top U.S. marketers from Fortune 1000 and Forbes Top 200 [29, p. 59], the investigated chief marketing officers feel an increasing pressure from their CEOs or boards to prove marketing's value.

\subsection{Research Methodology}

This section presents the main methodological coordinates of the research regarding Romanian industrial companies' market orientation and marketing performance measurement. This research comprised two distinct stages: the first stage was based on a qualitative approach consisting in conversation analysis, while the second stage was based on a quantitative approach, using a questionnaire as research instrument.

\subsubsection{The Qualitative Stage}

The qualitative phase of the research aimed to understand the market orientation of Romanian industrial companies in the first decade of transition. The investigation was based on the analysis of conversations between managers and

1 One of the most influential works on market orientation belongs to Slater and Narver [41], according to which this concept comprises three major components: customer orientation, competitor orientation and cross-functional coordination. 
students. From October 1994 to March 2000, 143 top managers of Romanian organisations met with undergraduate students of a management specialisation from the Technical University of Cluj-Napoca, Romania. The main objective of the meetings was to provide feedback from real-life management practitioners, from managers confronting the real problems of Romanian economy in that specific period of transition.

Almost all (98\%) participant managers led private, state-owned, or public organisations from Transylvania - the North-Western region of Romania. All managers graduated higher education institutions during the communist regime. A sample consisting of managers from industrial companies was selected for the purpose of this research. A sample of 75 managers resulted, representing 45 state owned companies and 30 private companies. It must be noted that the private companies were former state owned companies privatised after 1992.

This stage of the research was focused on information collected from the participant managers. The conversations were analysed in order to identify the segments related to four topics - market, market orientation, marketing and marketing performance. All discourse segments related and relevant to these topics were identified. The collected and structured information was analysed, interpreted and conclusions were drawn. The methodological approach used in the qualitative stage of the research was discourse analysis. All discourse analysis's approaches explore how elements of social reality are constituted through talk and text [35]. A significant amount of research exists employing discourse analysis as research method on organisational change. Discourse analysis as a research process is focused not only on conversation analysis and interpretation, but it was also based on a set of theoretical assumptions [48]. As noted in Sucala [45], the level of accuracy of managerial discourse can be estimated as reasonable. The conversations had an important degree of informality and the managers usually mentioned what they considered to be relevant for students.

\subsubsection{The Quantitative Stage}

The quantitative stage of the research targeted the investigation of marketing performance measurement practices used by the Romanian companies included in the National Top of Companies from Romania, an annual hierarchy of enterprises developed by the Chamber of Commerce and Industry of Romania. Some results of this research were partially disseminated in [7], [39]. However, for the purpose of this paper a new approach was undertaken including the use of a new sample of companies.

This research aimed to determine what aspects of marketing performance do the companies, included in the 2010 edition of the National Top of Companies from Romania, consider important to measure and what marketing performance measures they use for performing this assessment. 
As marketing performance is a multidimensional construct and multiple metrics should be used for its measurement [5], the research was focused on eight distinct dimensions of marketing performance: market performance, brand performance, customer performance, marketing's financial performance and the individual performance of each of the four components of the marketing mix - product, price, placement and promotion [39]. For each of these marketing performance dimensions, various performance indicators were selected as means of assessing the respective marketing performance dimension, resulting in a total number of 59 performance measures. The selection of indicators was based on previous recommendations from the marketing performance measurement literature [1], [4], [38], [26], [22], [16], [21].

The research method used was the total investigation of all the enterprises included in the previously mentioned top of companies (2143 companies). A questionnaire was created as the research instrument used for data collection. A five-point importance scale with anchors of "not at all important (1)" and "very important (5)" was used for respondents to indicate the importance levels attached to the measurement of each of the eight marketing performance dimensions, as well as for the importance assigned to each performance measure. Respondents were also asked to self-assess their company's ability of measuring each of the marketing dimensions and then the current level of the company's performance for each dimension of marketing performance, on a five-point scale anchored by "very weak (1)" and "very good (5)". Various descriptive data regarding investigated enterprises were collected in the end of the questionnaire, such as legal form, number of employees, turnover, main field of activity.

The questionnaire was applied via e-mail in June and July 2011 and 153 valid responses were obtained. This group of 153 companies includes enterprises of various sizes, from micro-enterprises to very large companies, and from different fields of activity: research and development and high-tech, industry, agriculture and fishery, building, services, and commerce [7].

Out of the responding 153 companies, a new sample was selected for the purpose of this research, consisting in companies satisfying two criteria - an industrial field of activity and a sufficient number of employees to rate the company as large. A new sample of 24 enterprises resulted, all of them being industrial companies with more than 250 employees. This group of 24 companies accounts for $10.25 \%$ of the total number of industrial large and very large companies included in the National Top of Companies from Romania (234 companies).

The structure of this sample of 24 companies, according to their turnover, indicates that over half of the investigated companies (54.2\%) had a turnover of more than 50 million Euro, 29.2\% of the companies had a turnover between 10-50 million Euro, while the remaining $16.6 \%$ of the companies had a turnover between 2-10 million Euro. According to the companies' legal form, three quarters of the 24 enterprises were organised as joint-stock companies, while the companies 
organised as limited liability companies accounted for the remaining $25 \%$ of the group. More than half of them (54.2\%) were companies with Romanian capital, $16.7 \%$ with foreign capital and $29.2 \%$ with mixed capital.

\section{Findings and Discussion}

\subsection{Market Orientation of the Romanian Industrial Companies in the First Decade of Transition}

As it was already presented in Sucala [45] the production-oriented mentality developed during communism was one of the main important factors blamed for the transition difficulties by managers of industrial companies. However, few managers admitted they preferred the centralised economy in which the main problems were to secure enough supplies and to fulfil the production targets. The transition to market economy raised new problems for which management and organisational structures were not thoroughly prepared.

The managers acknowledged the extremely low marketing performances, estimating a less than $5 \%$ of what marketing activity had to perform. After the demise of the hyper-centralised communist system, the managers discovered the new challenges of the market economy: sales and customer care instead of just supplying. The production-oriented mentality developed during more than four decades of communist industrialisation had become a major problem during the first part of transition.

For an organisation used to surviving in a hyper-centralised economy where all commercial relations were dictated by a central agency (State Commission of Planning), the new challenges of the market economy seemed extremely difficult. Market research, customers' needs investigation, promotion and many other marketing concepts, techniques and methods were almost unknown before and immediately after 1990. More than that, Romanian academic environment lacked all that knowledge, fields of study such as management, sociology or psychology being completely eliminated from the universities.

Another feature of the Romanian communist economy was the monopoly of a few import-export companies with all the connections of foreign partners. After 1990 the centralised foreign trade system was replaced by a multitude of small private companies. The Romanian producers experienced the lack of connections with external markets, the lack of knowledge and competences required for foreign trade and the lack of resources to sustain the export. 


\subsection{Marketing Performance of the Romanian Industrial Companies in the Second Decade of Transition}

A first result of the quantitative research indicated that most of the respondents (95.8\%) considered that there exists a relation between marketing performance and business performance. Moreover, $91.7 \%$ of the respondents believed that marketing performance measurement is important in the organisational performance context. The mean value attached by respondents to marketing performance assessment was 4 (out of 5), indicating that respondents considered that it's important to assess the company's overall marketing performance.

The mean value of the companies' abilities for measuring marketing performance was 3.87 (out of 5), a result suggesting that on average, the investigated companies have a slightly less than good ability for their marketing performance measurement. Over a third of the respondents (37.5\%) considered that their companies possessed very good abilities for assessing their marketing performance, while other $25 \%$ of the respondents self-assessed these abilities as good. The mean value of the companies' overall level of perceived marketing performance, was 3.92 (out of 5). One third of the respondents (33.3\%) selfassessed their organisation's current marketing performance as being very good, while over a third of the respondents (37.5\%) perceived as being good.

The respondents were next asked to assign an importance level for the measurement of each of the eight dimensions of marketing performance and to self-asses their company's measurement ability and current performance level respectively for each dimension. The results are presented in Table 2.

Table 2

Respondents' opinion regarding: the importance of assessing the marketing performance dimensions, company's ability of assessing the dimensions and company's current performance level for each dimension

\begin{tabular}{|l|c|c|c|}
\hline $\begin{array}{c}\text { Dimensions of } \\
\text { marketing performance }\end{array}$ & $\begin{array}{c}\text { Importance of } \\
\text { assessing the } \\
\text { performance } \\
\text { dimension } \\
\text { (mean value) }\end{array}$ & $\begin{array}{c}\text { Company's } \\
\text { ability of } \\
\text { assessing the } \\
\text { dimension } \\
\text { (mean value) }\end{array}$ & $\begin{array}{c}\text { Company's current } \\
\text { performance level } \\
\text { for the dimension } \\
\text { (mean value) }\end{array}$ \\
\hline Market performance & 4.58 & 4.21 & 3.92 \\
\hline Brand performance & 3.96 & 3.58 & 3.33 \\
\hline Customer performance & 4.46 & 4.29 & 3.96 \\
\hline Financial performance & 4.33 & 3.71 & 3.52 \\
\hline Product performance & 3.87 & 3.57 & 3.35 \\
\hline Price performance & 4.04 & 3.87 & 3.70 \\
\hline Placement performance & 3.86 & 3.46 & 3.21 \\
\hline Promotion performance & 4.13 & 3.83 & 3.67 \\
\hline
\end{tabular}


It resulted that the mean values for the ability of assessing the marketing performance dimensions were above 4 , which corresponded to a good ability, for only two out of the eight considered dimensions - the ability of assessing customer performance (4.29) and market performance respectively (4.21). The mean values of the companies' abilities for measuring the remaining six dimensions of marketing performance were below 4, suggesting average abilities for these dimensions' performance measurement. In what concerns the companies' current performance levels for each dimension, the results showed that the mean values for each dimension were less than 4 , where this value corresponded to a good performance level. However, the dimensions of marketing performance for which the highest mean values of performance were recorded were customer performance (mean value of 3.96) and market performance (3.92).

The next investigated aspects regarded the ten most used and the ten most important marketing indicators respectively, given that all the 24 companies were large enterprises and the right number of marketing measures used by a large firm is usually between eight and ten [5]. Table 3 presents the most used ten marketing indicators among the investigated companies, according to the percentage of respondents that reported using each indicator, as well as the ten measures that resulted as being the most important ones, according to the percentage of respondents that rated each indicator as "very important".

It resulted that most used ten marketing indicators among the investigated companies refer to the measurement of customer performance (five indicators) and marketing's financial performance (four indicators).

The top three indicators that emerged as the most important are the same as the most used ones and correspond to the financial performance dimension - sales, net profit, gross profit; over $70 \%$ of the respondents rated each of these performance measures as very important. The next important indicator was customer relative satisfaction, rated as very important by $62.5 \%$ of the respondents; this measure is a market-based one, as it reflects customers' satisfaction regarding the company's offer in comparison with competitors' offers. The following most important measures were four indicators used for assessing customer performance customer satisfaction, number of customer complaints, number of customers and customers' loyalty. The most important ten marketing performance measures were dominated by three financial indicators and four customer-based indicators.

The results suggest that although the respondents acknowledged the importance of measuring various dimensions of marketing performance, they still have plenty of room for improving their actual marketing performance and their abilities of performance measurement as well.

Based on the results from Table 3, it can be noted that seven out of the ten most used indicators also appeared in the list of the ten most important marketing performance indicators. This observation could suggest that investigated industrial companies put efforts into measuring what they consider important about 
marketing performance. Moreover, it is an encouraging result that companies used a combination of financial and non-financial measures for assessing their marketing performance, as this is a very important requirement for an adequate assessment of marketing performance.

A discrepancy was noted between the dimensions of marketing performance that respondents considered the most important to measure (market performance and customer performance) and the three financial indicators (sales, net profit, gross profit) that emerged as the most important indicators for marketing performance assessment. Nevertheless, two simple explanations can be suggested for the observed discrepancy: the accounting indicators are more easily measured than other customer-based measures, such as customer satisfaction or customer loyalty, and second, the use of these accounting measures is mandatory for the purpose of corporate financial reporting.

Table 3

The most used and the most important marketing indicators in the investigated companies

\begin{tabular}{|c|c|c|c|c|c|}
\hline \multicolumn{3}{|c|}{$\begin{array}{l}\text { The ten most used marketing indicators in } \\
\text { the investigated companies }\end{array}$} & \multicolumn{3}{|c|}{$\begin{array}{l}\text { The ten most important marketing } \\
\text { indicators in the investigated companies }\end{array}$} \\
\hline Indicators & $\begin{array}{l}\text { Correspond- } \\
\text { ing } \\
\text { dimension } \\
\text { of marketing } \\
\text { performance }\end{array}$ & $\begin{array}{l}\text { \% of } \\
\text { companies } \\
\text { that use the } \\
\text { indicator }\end{array}$ & Indicators & $\begin{array}{l}\text { Correspond- } \\
\text { ing } \\
\text { dimension of } \\
\text { marketing } \\
\text { performance }\end{array}$ & $\begin{array}{l}\% \text { of } \\
\text { respondents } \\
\text { that rate the } \\
\text { indicator as } \\
\text { "very } \\
\text { important" }\end{array}$ \\
\hline Sales & $\begin{array}{c}\text { Financial } \\
\text { performance }\end{array}$ & 100 & Sales & $\begin{array}{l}\text { Financial } \\
\text { performance }\end{array}$ & 79.2 \\
\hline Net profit & $\begin{array}{c}\text { Financial } \\
\text { performance }\end{array}$ & 100 & Net profit & $\begin{array}{c}\text { Financial } \\
\text { performance }\end{array}$ & 75.0 \\
\hline Gross profit & $\begin{array}{c}\text { Financial } \\
\text { performance }\end{array}$ & 100 & $\begin{array}{l}\text { Gross } \\
\text { profit }\end{array}$ & $\begin{array}{c}\text { Financial } \\
\text { performance }\end{array}$ & 70.8 \\
\hline $\begin{array}{l}\text { Number of } \\
\text { customers }\end{array}$ & $\begin{array}{c}\text { Customer } \\
\text { performance }\end{array}$ & 100 & $\begin{array}{c}\text { Customer } \\
\text { relative } \\
\text { satisfaction }\end{array}$ & $\begin{array}{c}\text { Market } \\
\text { performance }\end{array}$ & 62.5 \\
\hline $\begin{array}{l}\text { Number of } \\
\text { customer } \\
\text { complaints }\end{array}$ & $\begin{array}{c}\text { Customer } \\
\text { performance }\end{array}$ & 100 & $\begin{array}{l}\text { Customer } \\
\text { satisfaction }\end{array}$ & $\begin{array}{l}\text { Customer } \\
\text { performance }\end{array}$ & 58.3 \\
\hline $\begin{array}{l}\text { Customer } \\
\text { satisfaction }\end{array}$ & $\begin{array}{c}\text { Customer } \\
\text { performance }\end{array}$ & 95.8 & $\begin{array}{c}\text { Number of } \\
\text { customer } \\
\text { complaints }\end{array}$ & $\begin{array}{c}\text { Customer } \\
\text { performance }\end{array}$ & 58.3 \\
\hline $\begin{array}{l}\text { Number of } \\
\text { new } \\
\text { customers } \\
\text { gained in a } \\
\text { specific } \\
\text { time period }\end{array}$ & $\begin{array}{c}\text { Customer } \\
\text { performance }\end{array}$ & 95.8 & $\begin{array}{l}\text { Number of } \\
\text { customers }\end{array}$ & $\begin{array}{c}\text { Customer } \\
\text { performance }\end{array}$ & 54.2 \\
\hline $\begin{array}{l}\text { Marketing } \\
\text { spending }\end{array}$ & $\begin{array}{c}\text { Financial } \\
\text { performance }\end{array}$ & 95.8 & $\begin{array}{c}\text { Customers' } \\
\text { loyalty }\end{array}$ & $\begin{array}{c}\text { Customer } \\
\text { performance }\end{array}$ & 54.2 \\
\hline
\end{tabular}




\begin{tabular}{|c|c|c|c|c|c|}
\hline $\begin{array}{c}\text { Profit per } \\
\text { customer }\end{array}$ & $\begin{array}{c}\text { Customer } \\
\text { performance }\end{array}$ & 91.7 & $\begin{array}{c}\text { Brand } \\
\text { awareness }\end{array}$ & $\begin{array}{c}\text { Brand } \\
\text { performance }\end{array}$ & 54.2 \\
\hline $\begin{array}{c}\text { Product } \\
\text { perceived } \\
\text { quality }\end{array}$ & $\begin{array}{c}\text { Product } \\
\text { performance }\end{array}$ & 91.7 & $\begin{array}{c}\text { Product } \\
\text { perceived } \\
\text { quality }\end{array}$ & $\begin{array}{c}\text { Product } \\
\text { performance }\end{array}$ & 54.2 \\
\hline
\end{tabular}

\subsection{Conclusions, Research Limitations and Future Directions of Research}

The first conclusion regards the awareness of the marketing impact on the overall company's performance. As the main findings indicate, the managers of Romanian industrial companies were aware of this importance even in the first decade of transition. They lacked the connections, knowledge, capabilities and resources to develop the marketing activity at a sufficient level in the turbulent period of transition to market economy.

At the end of the second decade of transition, almost all investigated companies regarded business performance as related with marketing performance. However the companies' average ability to measure marketing performance was slightly less than good. The dimensions of marketing performance that emerged as most important to measure were market performance (mean value 4.58), customer performance (4.46) and marketing's financial performance (4.33).

Some limitations of this research should be noted. The main limitation regard the complex methodology - the methodologies used to collect data in the two stages of the research differ significantly in terms of approach, instrument and sample. The information collected from the first decade of transition is qualitative, obtained through analysis of conversation between a sample of managers and students. Ten years later, a quantitative approach had been used. A sample of companies was selected from the National Top of Companies. Therefore no valid statement can be made regarding the comparability of the two sets of results. The aspect of the first sample's representativeness cannot be discussed, but taking into consideration the homogeneity of the communist industrial organisations in terms of structure and main activities, and the limited reforms pursued in the first decade of transition, it can be argued with a certain degree of confidence that the findings characterised most of Romanian industrial companies in that period.

The second set of investigated industrial companies is relatively reduced -24 companies, therefore the findings cannot be generalised. Nevertheless, the results can provide a useful insight into what these companies consider important to measure about their marketing performance. Although the selection of the eight dimensions of marketing performance and of the measures that can be used for each of this dimension's measurement was based on literature review, further research could refine these categories of marketing performance dimensions and indicators, given the richness of the marketing literature in this respect. 
A particular area for future research consists in exploring the relationships between Romanian industrial companies' market orientation, their marketing performance and their marketing performance measurement practices. The concept of market orientation is the marketing concept with the broadest range of application and it can be applied to organisations of all sizes and from all industries [27]. However, previous findings showed that the relationships between market orientation and business performance seem to be stronger in organisations from developed economies than in organisations from emerging countries [14]; therefore, further research in this area could be done taking into account different national culture contexts [24], [30].

\section{References}

[1] Aaker, D. A.: Building Strong Brands, The Free Press, New York, 1996

[2] Ahrend, R. and Oliveira, J. M.: Creative Destruction or Destructive Perpetuation: The Role of Large State-owned Enterprises and SMEs in Romania during Transition, Post-Communist Economies, 15 (3), pp. 331356, 2003

[3] Ambler, T. and Xiucun, W.: Measures of Marketing Success: a Comparison between China and the United Kingdom, Asia Pacific Journal of Management, 20, pp. 267-281, 2003

[4] Ambler, T., Kokkinaki, F. and Puntoni, S.: Assessing Marketing Performance: Reasons for Metrics Selection, Journal of Marketing Management, 20, pp. 475-498, 2004

[5] Ambler, T. and Roberts, J.: Beware the Silver Metric: Marketing Performance Measurement has to be Multidimensional, London Business School, Centre for Marketing Working Paper, No. 05-709, September 2005

[6] Axenciuc, V.: Introduction in the Economic History of Romania, Editura Fundaţiei România de Mâine, Bucharest, 1997 (Romanian edition)

[7] Bacali, L. and Sava, A. M.: Assessment of the Importance of Market Performance Indicators for the Firms from the National Top of Romania (I), Actual Problems of Economics, 1 (139), pp. 236-245, 2013

[8] Baranyai, Z., Gyuricza, C. and Vasa, L.: Moral Hazard Problem and Cooperation Willingness: some Experiences from Hungary, Actual Problems of Economics, 12 (138), pp. 301-310, 2012

[9] Brooks, N. and Simkin, L.: Judging Marketing Mix Effectiveness, Marketing Intelligence \& Planning, 30 (5), pp. 494-514, 2012

[10] Brown, V. F.: The Movement for Reform in Rumania after World War I: The Parliamentary Bloc Government of 1919-1920, Slavic Review, 38, 3, 1979 
[11] Constantin, D. L., Goschin, Z. and Danciu, A. R.: The Romanian Economy from Transition to Crisis. Retrospects and Prospects, World Journal of Social Sciences, 1 (3), pp. 155-171, July 2011

[12] Csaba, L.: From Sovietology to Neo-Institutionalism, Post-Communist Economies, 21 (4), pp. 383-398, 2009

[13] Daianu, D. and Murgescu, B.: Which Way Goes Romanian Capitalism? Making a Case for Reforms, Inclusive Institutions and a Better Functioning European Union, Romanian Journal of European Affairs, 13 (4), pp. 5-34, December 2013

[14] Ellis, P. D.: Market Orientation and Marketing Practice in a Developing Economy, European Journal of Marketing, 39 (5/6), pp. 629-645, 2005

[15] Eusebio, R., Andreu, J. L. and Lopez Belbeze, M. P.: Measures of Marketing Performance: a Comparative Study from Spain, International Journal of Contemporary Hospitality Management, 18 (2), pp. 154-155, 2006

[16] Farris, P. W., Bendle, N. T., Pfeifer, P. E. and Reibstein, D. J: Marketing Metrics: the Definitive Guide to Measuring Marketing Performance, $2^{\text {nd }}$ edition, Pearson Education, New Jersey, 2010

[17] Hollinshead, G. and Michailova, S.: Blockbusters or Bridge-Builders? The Role of Western Trainers in Developing New Entrepreneurialism in Eastern Europe, Management Learning, 32 (3), pp. 377-394, 2001

[18] Hunya, G.: Romania 1990-2002: Stop-Go Transformation, PostCommunist Economies, 10 (2), pp. 241-258, 1998

[19] Ionete, C.: The System Crisis of the Command Economy and Its Explosive Phase, Editura Expert, Bucharest, 1993 (Romanian edition)

[20] Janos, A. C.: The Politics of Backwardness in Hungary 1825-1945, Princeton University Press, New Jersey, 1982

[21] Jeffery, M.: Data Driven-Marketing: the 15 Metrics Everyone in Marketing should Know, John Wiley \& Sons, New Jersey, 2010

[22] Keller, K. L. and Lehmann, D. R.: Brands and Branding: Research Findings and Future Priorities, Marketing Science, 25 (6), pp. 740-759, 2006

[23] King, R. R.: History of the Romanian Communist Party, Hoover Institution Press, Stanford, 1980

[24] Kirca, A. H., Jayachandran, S. and Bearden, W. O.: Market Orientation: a Meta-Analytic Review and Assessment of its Antecedents and Impact on Performance, Journal of Marketing, 69, pp. 24-41, April 2005

[25] Kornai, J.: The Socialist System. The Political Economy of Communism, Clarendon Press, Oxford, 1992 
[26] Kotler, P. and Keller, K. L.: Marketing Management, $12^{\text {th }}$ edition, Upper Saddle River, Pearson Prentice Hall, New Jersey, 2006

[27] Liao, S.-H., Chang, W.-J., Wu, C.-C. and Katrichis, J. M.: A Survey of Market Orientation Research (1995-2008), Industrial Marketing Management, 40, pp. 301-310, 2011

[28] Mintz, O. and Currim I. S.: What Drives Managerial Use of Marketing and Financial Metrics and does Metric Use Affect Performance of MarketingMix Activities?, Journal of Marketing, 77, pp.17-40, March 2013

[29] Moorman, C.: The CMO Survey Highlights and Insights, August 2013, available online at www.cmosurvey.org

[30] Morgan, N. A., Vorhies, D. W. and Mason, C. H.: Research Notes and Commentaries: Market Orientation, Marketing Capabilities and firm Performance, Strategic Management Journal, 30, pp. 909-920, 2009

[31] Murgescu, B.: Romania and Europe. The Accumulation of Economic Disparities (1500-2010), Polirom, Iasi, 2010 (Romanian edition)

[33] Nwokah, N. G.: Customer-Focus, Competitor-Focus and Marketing Performance, Measuring Business Excellence, 13 (3), pp. 20-28, 2009

[34] Pakulski, J., Kullberg, J. and Higley, J.: The Persistence of Postcommunist Elites, Journal of Democracy, 7 (2), pp. 133-147, 1996

[35] Phillips, N. and DiDomenico, M. L.: Discourse Analysis in Organizational Research: Methods and Debates, in Buchanan, D. A. and Bryman, A. (eds.) 2009

[36] Roberts, H. L.: Romania. Political Problems of an Agrarian State, Yale University Press, New Haven, 1951

[38] Rust, R. T., Ambler, T., Carpenter, G. S., Kumar, V. and Srivastava, R. K.: Measuring Marketing Productivity: Current Knowledge and Future Directions, Journal of Marketing, 68, pp. 76-89, October 2004

[39] Sava, A. M. and Bacali, L.: Assessment of the Importance of Market Performance Indicators in Firms from the National Top of Romania (II), Actual Problems of Economics, 4 (142), pp. 472-479, 2013

[40] Scarlat, C. and Rucinska, S.: Some Considerations on Ending the Process of Economic Transition in Romania and Slovakia, European Research Studies, XII (1), pp. 169-188, 2010

[41] Slater, S. F. and Narver, J. C.: Market Orientation, Customer Value and Superior Performance, Business Horizons, pp. 22-28, March-April 1994

[42] Sucala, I. V.: Elites on Transition: Post-Communist Experience, The $6^{\text {th }}$ International Critical Management Studies Conference, Warwick, July 2009 
[43] Sucala, I. V., and Kostina, S.: Cross-Cultural Management - from West to East (1), Actual Problems of Economics, No. 7 (109) 2010

[44] Sucala, I. V.: Cross-Cultural Management - Theory \& Method (2), Actual Problems of Economics, No. 6 (120), 2011

[45] Sucala, I. V.: Managers of Transition - Leadership in the Post-Communist Romanian Companies, Europe Asia-Studies, Vol. 67, Issue 4, 2015

[46] Tismaneanu, V., Dobrincu, D. and Vasile C.: Final Report of the Presidential Committee for the Analysis of the Communist Dictatorship in Romania, Humanitas, Bucharest, 2007 (Romanian edition)

[47] Vasa L. and Palmai, E.: Indicative Planning at National Level as a Tool for Strategic Planning - the Case of Hungary, Nauchnye Trudy Volnogo Ekonomicheskogo Obschestva Rossii, 175, pp. 324-349, 2013

[48] Wood, L. A. and Kroger, R. O.: Doing Discourse Analysis: Methods for Studying Action in Talk ant Text, Sage Publications, Thousand Oaks, 2000 